\title{
Reduction and immobilization of chromate in chromite ore processing residue with nanoscale zero-valent iron
}

\author{
Jingjing $\mathrm{Du}^{\mathrm{a}}$, Jinsuo $\mathrm{Lu}^{\mathrm{b}}$, Qiong $\mathrm{Wu}^{\mathrm{a}}$, Chuanyong Jing ${ }^{\mathrm{a}, *}$ \\ a State Key Laboratory of Environmental Chemistry and Ecotoxicology, Research Center for Eco-Environmental Sciences, Chinese Academy of Sciences, Beijing 100085, China \\ ${ }^{\mathrm{b}}$ School of Environmental and Municipal Engineering, Xi'an University of Architecture and Technology, Xi'an 710055, China
}

\section{A R T I C L E I N F O}

\section{Article history:}

Received 13 October 2011

Received in revised form 13 February 2012

Accepted 17 February 2012

Available online 24 February 2012

\section{Keywords:}

Chromite ore processing residue (COPR)

Nanoscale zero-valent iron (nZVI)

$\mathrm{X}$-ray absorption near edge structure

(XANES) spectroscopy

Chromate leachability

Speciation

\begin{abstract}
A B S T R A C T
Chromite ore processing residue (COPR) poses a great environmental and health risk with persistent $\mathrm{Cr}(\mathrm{VI})$ leaching. To reduce $\mathrm{Cr}(\mathrm{VI})$ and subsequently immobilize in the solid matrix, COPR was incubated with nanoscale zero-valent iron (nZVI) and the $\mathrm{Cr}(\mathrm{VI})$ speciation and leachability were studied. Multiple complementary analysis methods including leaching tests, X-ray powder diffraction, X-ray absorption near edge structure (XANES) spectroscopy, and X-ray photoelectron spectroscopy (XPS) were employed to investigate the immobilization mechanism. Geochemical PHREEQC model calculation agreed well with our acid neutralizing capacity experimental results and confirmed that when $\mathrm{pH}$ was lowered from 11.7 to 7.0 , leachate $\mathrm{Cr}(\mathrm{VI})$ concentrations were in the range $358-445 \mathrm{mg} \mathrm{L}^{-1}$ which contributed over $90 \%$ of dissolved $\mathrm{Cr}$ from COPR. Results of alkaline digestion, XANES, and XPS demonstrated that incubation COPR with nZVI under water content higher than $27 \%$ could result in a nearly complete $\mathrm{Cr}(\mathrm{VI})$ reduction in solids and less than $0.1 \mathrm{mg} \mathrm{L}^{-1} \mathrm{Cr}(\mathrm{VI})$ in the TCLP leachate. The results indicated that remediation approaches using nZVI to reduce $\mathrm{Cr}(\mathrm{VI})$ in COPR should be successful with sufficient water content to facilitate electron transfer from nZVI to COPR.
\end{abstract}

(C) 2012 Elsevier B.V. All rights reserved.

\section{Introduction}

Chromium contamination of soil, sediment, and water has received increasing attention because of its severe impact on public health. Common $\mathrm{Cr}$ exposure pathways include ingestion, inhalation, and dermal contact. The primary health impacts from $\mathrm{Cr}$ are damages to the gastrointestinal, respiratory, and immunological systems, as well as reproductive and developmental problems [1]. Recently, a study from the U.S. National Institute of Health suggested that drinking water containing hexavalent chromium $\mathrm{Cr}(\mathrm{VI})$, a human carcinogen with an inhalation exposure pathway, could lead to cancer [1]. Among various forms of $\mathrm{Cr}$ contamination, the chromite ore processing residue (COPR) possess a great environmental and health risk with persistent $\mathrm{Cr}(\mathrm{VI})$ release at appreciable concentrations [2,3]. In addition to inhalation and drinking, incidental ingestion of $\mathrm{Cr}$-containing dusts is a potential important exposure route for nearby residents. Although the high-lime process responsible for such COPR generation was abandoned in the U.S. and the U.K. by the late 1960s, it is still being used in countries such as China and India [4,5]. About 1 million tonnes of COPR are produced each year in China and more than 6 million tonnes of COPR was stored in heaps [6]. The fact that $\operatorname{Cr}(\mathrm{VI})$ is

\footnotetext{
* Corresponding author. Tel.: +86 106284 9523; fax: +861062849523.

E-mail address: cyjing@rcees.ac.cn (C. Jing).
}

incorporated in the COPR solid matrix rather than on particle surfaces makes it a great challenge to reduce and immobilize $\mathrm{Cr}(\mathrm{VI})$ in COPR [7].

Stabilization/solidification (S/S) technology with Portland cement is commonly used for the treatment of soils contaminated with heavy metals including $\mathrm{Cr}$ [8]. The $\mathrm{Cr}$ leachability in S/S treated samples is determined by its oxidation state, and $\mathrm{Cr}(\mathrm{VI})$ is readily leachable. Meanwhile, the $\mathrm{S} / \mathrm{S}$ additives are not effective in reducing $\mathrm{Cr}(\mathrm{VI})$ to $\mathrm{Cr}(\mathrm{III})$ [9]. Effective reductants should be added before cement addition to solidify the contaminated soils [10].

The $\mathrm{Cr}(\mathrm{VI})$ reductants generally include S-containing species [2,11-13], and ferrous iron [3,14]. The reduction using S-containing species was generally not satisfactory with respect to the residual $\mathrm{Cr}(\mathrm{VI})$ content in COPR. Although TCLP leachate $\mathrm{Cr}(\mathrm{VI})$ concentration was lower than $5 \mathrm{mg} \mathrm{L}^{-1}$, in situ XANES analysis demonstrated that the residual $\mathrm{Cr}(\mathrm{VI})$ content was as high as $610.2 \mathrm{mg} \mathrm{kg}^{-1}$ [15]. On the other hand, ferrous iron has been most extensively studied and proven to be an effective reductant of $\mathrm{Cr}(\mathrm{VI})$ at acidic and neutral $\mathrm{pH}$ [16]. However, it cannot successfully remediate highlime COPR because its mineralogical complexity prevents effective $\mathrm{Cr}(\mathrm{VI})$ availability for subsequent conventional chemical reduction $[3,17]$. In recent years nanoscale zero-valent iron (nZVI) has been developed and demonstrated to be an effective reductant for the immobilization of $\mathrm{Cr}(\mathrm{VI})$ in water and soils [18-21]. Nevertheless, limited research is conducted on the leachability and speciation of $\mathrm{Cr}$ in COPR in the presence of nZVI [22]. 
The objectives of this study were to (1) explore the $\mathrm{Cr}$ immobilization mechanism in COPR in the presence of nZVI, (2) evaluate the effects of nZVI dosage and water content on $\mathrm{Cr}(\mathrm{VI})$ reduction, and (3) identify the $\mathrm{Cr}$ speciation in COPR with multiple complimentary techniques including X-ray absorption near edge structure (XANES) spectroscopy and X-ray photoelectron spectroscopy (XPS). The complete $\mathrm{Cr}(\mathrm{VI})$ reduction and immobilization with nZVI shed new light on COPR remediation.

\section{Materials and methods}

\subsection{Sample preparation}

COPR samples were collected from an industrial waste site at Jinan, China. The samples were passed through a 60-mesh $(0.25 \mathrm{~mm})$ sieve to remove large particles. The sieved samples were dried at $80^{\circ} \mathrm{C}$ and stored in capped containers. The cement used in our experiment is the Portland cement, which was obtained from Anhui CONCH Cement Company. The water content listed in Table 1 was calculated using Eq. (1):

Water $\%=\frac{m_{\text {water }}(\mathrm{g})}{m_{\text {water }}(\mathrm{g})+m_{\mathrm{nZVI}}(\mathrm{g})+m_{\mathrm{COPR}}(\mathrm{g})} \times 100 \%$

The nZVI particles were synthesized according to the method introduced by Wang and Zhang [23]. Briefly, solutions of ferric chloride $(0.045 \mathrm{M})$ and potassium borohydride $(0.25 \mathrm{M})$ were mixed with $1: 1 \mathrm{v} / \mathrm{v}$ ratio. The formed nanoparticles were separated from the solution using vacuum filtration, and then washed with distilled water and $5 \%$ ethanol.

For the nZVI incubation treatment, $0 \%$ (Inc-0 as a control sample), $1 \%$ (Inc-1), 2\% (Inc-2), 3\% (Inc-3), 4\% (Inc-4), 6\% (Inc-6), and $10 \%$ (Inc-10) nZVI (wt. nZVI/wt. dry COPR) were mixed with $15 \mathrm{~g}$ COPR in a glove box $\left(100 \% \mathrm{~N}_{2}\right)$. The samples were incubated with saturated water content (28-36\%) in wide mouth glass bottles in darkness for $180 \mathrm{~d}$ to study the durability and stability of the nZVI treatment. This water saturation was operationally achieved by adding DI water dropwisely till free water (unbounded with particles) was observed. At designed times, the samples were used in batch extraction tests to evaluate $\mathrm{Cr}(\mathrm{VI})$ leachability.

To explore a two-step COPR remediation route, i.e., nZVI incubation followed by cement stabilization, sub-samples of Inc-0, Inc-2, Inc- 6 , and Inc- 10 were mixed with $25 \%$ cement (wt. cement/wt. dry COPR) after incubated for $7 \mathrm{~d}$. The cement treated samples denoted as CInc-0, CInc-2, CInc-6, and CInc-10 were stored in sealed sample bags and cured at room temperature for another $7 \mathrm{~d}$.

To confirm the nZVI optimum dosage under constant water content, increasing amounts of nZVI from 0 to $10 \%$ were mixed with $15 \mathrm{~g}$ COPR. The samples named as WInc-0, WInc- 2 , WInc- 6 , and WInc-10 under the same water content (33\%) were incubated in wide mouth glass bottles in darkness for $7 \mathrm{~d}$.

To evaluate the effect of water content on the COPR stabilization using nZVI, various amount of water was added into Inc- 6 sample to reach water content ranging from $23 \%$ to $33 \%$. The samples were incubated for $7 \mathrm{~d}$.

Conventional S/S treatment with Portland cement and nZVI were also employed as control and the treatment procedure was the same as our previous report [24]. Briefly, COPR samples were mixed with $10 \%$ cement $(10 \% \mathrm{C}), 25 \%$ cement ( $25 \% \mathrm{C}), 2.5 \% \mathrm{nZVI}(2.5 \% \mathrm{Fe})$, $6 \% \mathrm{nZVI}(6 \% \mathrm{Fe})$, a series of combinations of $10 \%$ cement and $2.5 \%$ nZVI (LCLFe), 10\% cement and 6\% nZVI (LCHFe), 25\% cement and $2.5 \%$ nZVI (HCLFe), and 25\% cement and 6\% nZVI (HCHFe), respectively. The mixtures were compacted according to ASTM D 1557-91 standard. The compacted specimens were stored in sealed sample bags and cured at room temperature for $28 \mathrm{~d}$. Then, the solids were pulverized and used in batch extraction tests.

\subsection{Experiments}

Total metal contents were determined according to USEPA method 3050B [25] and analyzed using inductively coupled plasma optical emission spectrometry (ICP-OES Optima 2000 DV, Perkin Elmer Co., USA) with a detection limit of $100 \mu \mathrm{g} \mathrm{L}^{-1}$. Alkaline digestion test was conducted to determine $\mathrm{Cr}(\mathrm{VI})$ content in solid samples following USEPA method 3060A [26]. The soluble $\mathrm{Cr}(\mathrm{VI})$ concentrations were determined using a Hach DR 2800 Spectrophotometer based on USEPA method 7196A [27] with a detection limit of $20 \mu \mathrm{g} \mathrm{L}^{-1}$. The Fe(II) concentration was measured using 3500-Fe B phenanthroline colorimetric method [28] with a detection limit of $50 \mu \mathrm{g} \mathrm{L}^{-1}$. XANES data were collected at the BL3C1 beamline at Pohang Light Source, South Korea for Cr speciation analysis. XPS, X-ray powder diffraction, and energy dispersive $\mathrm{X}$-ray spectrometry for mineralogical analysis were performed. A complete description of data collection and analysis is provided in supplementary material.

General acid neutralizing capacity (GANC) test was performed following the procedures described in a previous report [29]. Eleven single batch extractions were performed in parallel. After $48 \mathrm{~h}$ tumbling at a $\mathrm{L} / \mathrm{S}$ ratio of 20 , the equilibrium $\mathrm{pH}$ and soluble $\mathrm{Cr}$ concentration were measured. Toxicity characteristic leaching procedure (TCLP) was employed to determine the $\mathrm{Cr}(\mathrm{VI})$ leachability according to USEPA method 1311 [30]. A 0.1 M acetic acid solution with a $\mathrm{pH}$ of 2.88 was used as leachant. The COPR samples were extracted at a liquid to solid (L/S) ratio of 20 in capped polypropylene bottles on a rotary tumbler at $30 \mathrm{rpm}$ for $18 \mathrm{~h}$. After the extraction, the final $\mathrm{pH}$ of the leachate was measured and the liquid was separated from the solids by filtration through a $0.45 \mu \mathrm{m}$ glass fiber filter. A Chinese leaching protocol, solid waste extraction procedure for leaching toxicity: sulfuric acid and nitric acid method (HJ/T299-2007) [31], was also employed and referred to HJ. Synthetic acid rain water was used as leachant in $\mathrm{HJ}$ by mixing sulfuric acid and nitric acid (60/40, w/w) at pH 3.20. COPR samples were extracted at a liquid to solid (L/S) ratio of 10 on a rotary tumbler at $30 \mathrm{rpm}$ for $18 \mathrm{~h}$. At the end of the leaching tests, $\mathrm{pH}$ and Eh were monitored and soluble metal concentrations were determined.

The adsorption diffuse layer model (DLM) was employed to describe the leachability of $\mathrm{Cr}$ and $\mathrm{Cr}(\mathrm{VI})$ in the GANC test. The chemical equilibrium computer program PHREEQC Version 2.18 with DLM adsorption option was used to simulate adsorption, precipitation, and aqueous reactions [32]. Default equilibrium constants in MINTEQ and LLNL database were used in the calculation. Details of the model parameters are presented in Table S2 in the supplementary material.

\section{Results and discussion}

\subsection{Characterization of COPR}

\subsubsection{Total metal content}

The metal contents in COPR are shown in Table S1 (supplementary material). The total $\mathrm{Cr}$ in COPR was $43.2 \mathrm{~g} \mathrm{~kg}^{-1}$. The $\mathrm{Cr}(\mathrm{VI})$ content determined using alkaline digestion was $15.9 \mathrm{~g} \mathrm{~kg}^{-1}$, which was approximately $37 \%$ of total chromium. The calcium and iron content was 191 and $62.3 \mathrm{~g} \mathrm{~kg}^{-1}$, respectively. The high calcium concentration and the high $\mathrm{pH}$ at 11.7 were the result of the high-lime processing of chromite ore for chromate production. COPR sample also contained magnesium $\left(72.4 \mathrm{~g} \mathrm{~kg}^{-1}\right)$, sodium (36.7 $\left.\mathrm{g} \mathrm{kg}^{-1}\right)$, and potassium $\left(4.7 \mathrm{~g} \mathrm{~kg}^{-1}\right)$.

\subsubsection{GANC}

Acetic acid was used to determine the GANC and the metal leachability. When the leachant acidity increased from 0 to 
Table 1

Physical and chemical properties, and leaching tests results for nZVI incubation samples.

\begin{tabular}{|c|c|c|c|c|c|c|c|c|c|}
\hline \multirow[t]{2}{*}{ Sample } & \multirow[t]{2}{*}{ Water, \% } & \multicolumn{4}{|c|}{ TCLP } & \multicolumn{4}{|l|}{$\mathrm{HJ}$} \\
\hline & & $\mathrm{pH}$ & $\mathrm{Eh}(\mathrm{mV})$ & $\mathrm{Cr}(\mathrm{VI})\left(\mathrm{mg} \mathrm{L}^{-1}\right)$ & Total $\mathrm{Cr}\left(\mathrm{mg} \mathrm{L}^{-1}\right)$ & $\mathrm{pH}$ & $\mathrm{Eh}(\mathrm{mV})$ & $\mathrm{Cr}(\mathrm{VI})\left(\mathrm{mg} \mathrm{L}^{-1}\right)$ & Total $\mathrm{Cr}\left(\mathrm{mg} \mathrm{L}^{-1}\right)$ \\
\hline COPR & 15 & 9.1 & - & $330 \pm 39$ & - & 11.6 & - & $453 \pm 36$ & - \\
\hline Inc- $0^{\mathrm{a}}$ & 28 & 9.2 & 190 & $309 \pm 28$ & $312 \pm 12$ & 11.5 & 36 & $451 \pm 21$ & $527 \pm 42$ \\
\hline Inc- $2^{\mathrm{a}}$ & 31 & 8.9 & 87 & $64.3 \pm 1.7$ & $74.1 \pm 4.7$ & 11.1 & 23.7 & $84.0 \pm \pm 1.0$ & $101 \pm 25$ \\
\hline Inc- $6^{a}$ & 34 & 7.5 & -459 & N.D. ${ }^{c}$ & N.D. ${ }^{c}$ & 9.7 & -435 & N.D. ${ }^{c}$ & N.D. ${ }^{c}$ \\
\hline Inc- $10^{\mathrm{a}}$ & 36 & 7.2 & -461 & N.D. ${ }^{c}$ & N.D. ${ }^{c}$ & 8.8 & -455 & N.D. ${ }^{c}$ & N.D. ${ }^{c}$ \\
\hline CInc- $-0^{b}$ & 20 & 9.4 & 174 & $168 \pm 6.1$ & $201 \pm 22$ & 12.4 & -87 & $229 \pm 25$ & $286 \pm 33$ \\
\hline CInc- $2^{b}$ & 23 & 9.2 & 115 & $32.1 \pm 2.2$ & $40.3 \pm 2.5$ & 11.9 & -131 & $40.6 \pm 0.29$ & $53.1 \pm 1.7$ \\
\hline CInc- $6^{\mathrm{b}}$ & 24 & 7.8 & -325 & N.D. ${ }^{c}$ & N.D. ${ }^{c}$ & 10.7 & -167 & N.D. ${ }^{c}$ & N.D. ${ }^{c}$ \\
\hline CInc- $10^{\mathrm{b}}$ & 24 & 7.5 & -329 & N.D. ${ }^{c}$ & N.D. ${ }^{c}$ & 9.6 & -323 & N.D. ${ }^{c}$ & N.D. ${ }^{c}$ \\
\hline WInc- $0^{\mathrm{a}}$ & 33 & 8.8 & 231 & $308 \pm 34$ & $319 \pm 29$ & 11.3 & 111 & $364 \pm 8.1$ & $507 \pm 16$ \\
\hline WInc- $2^{\mathrm{a}}$ & 33 & 8.6 & 210 & $92.1 \pm 20$ & $115 \pm 17$ & 10.5 & 104 & $102 \pm 3.2$ & $121 \pm 9.3$ \\
\hline WInc- $6^{\mathrm{a}}$ & 33 & 7.3 & -318 & N.D. ${ }^{c}$ & N.D. ${ }^{c}$ & 9.5 & -304 & N.D. ${ }^{c}$ & N.D. ${ }^{c}$ \\
\hline WInc- $10^{\mathrm{a}}$ & 33 & 7.2 & -423 & N.D. ${ }^{c}$ & N.D. ${ }^{c}$ & 8.8 & -368 & N.D. ${ }^{c}$ & N.D. ${ }^{c}$ \\
\hline
\end{tabular}

a The samples were incubated for $7 \mathrm{~d}$.

b The samples were incubated for $7 \mathrm{~d}$ and mixed with $25 \%$ cement for another $7 \mathrm{~d}$.

c The concentration was below the detection limit.

15 eq $\mathrm{H}^{+} \mathrm{kg}^{-1}$, the solution $\mathrm{pH}$ decreased from 11.7 to 5.3 (Fig. 1a). Approximately $2 \mathrm{eq}^{+} \mathrm{kg}^{-1}$ acidity was needed to attain $\mathrm{pH}$ value at about 9. The GANC results from PHREEQC calculation are also presented in Fig. 1, which fits reasonably well with the experimental data. Both observed and model calculated results showed that when $\mathrm{pH}$ was lowered from 11.7 to $7.0, \mathrm{Cr}(\mathrm{VI})$ concentrations slightly ascended from 358 to $445 \mathrm{mg} \mathrm{L}^{-1}$ which contributed over $90 \%$ of dissolved $\mathrm{Cr}$ (Fig. 1b). Upon pH further declined to less than $6, \mathrm{Cr}(\mathrm{III})$ and Fe concentrations were elevated exponentially while $\mathrm{Cr}(\mathrm{VI})$ concentration was slightly increased up to about $500 \mathrm{mg} \mathrm{L}^{-1}$. The sharp increase of $\mathrm{Cr}$ (III) and Fe leachability occurred when acidity was higher than $9 \mathrm{eq} \mathrm{kg}^{-1}$ (Fig. 1c). The correlation of $\mathrm{Cr}$ (III) and $\mathrm{Cr}(\mathrm{VI})$ concentrations with the concentration of $\mathrm{Fe}$ is shown in Fig. 1d. The correlation coefficient of a linear regression model was $0.80\left(\right.$ slope $\left.=0.07, p=1.05 \times 10^{-4}\right)$ for $\mathrm{Cr}(\mathrm{VI})$ and 0.95 (slope $=0.64$, $p=8.04 \times 10^{-9}$ ) for $\mathrm{Cr}(\mathrm{III})$. The dashed lines in Fig. 1d show the $99 \%$ confidence limits. The amount of $\mathrm{Cr}$ released was positively related to the amount of Fe dissolved from COPR.

GANC results showed that about $42-65 \% \mathrm{Cr}(\mathrm{VI})$ were available in aqueous phase upon $\mathrm{pH}$ decreased from 11.7 to 5.3 (Fig. 1b and c). On the other hand, about $50 \% \mathrm{Cr}(\mathrm{VI})$ were associated with solid phase in a wide $\mathrm{pH}$ range. This high percentage of solid association might be the major challenge for effective $\mathrm{Cr}(\mathrm{VI})$ reduction and COPR remediation [7].
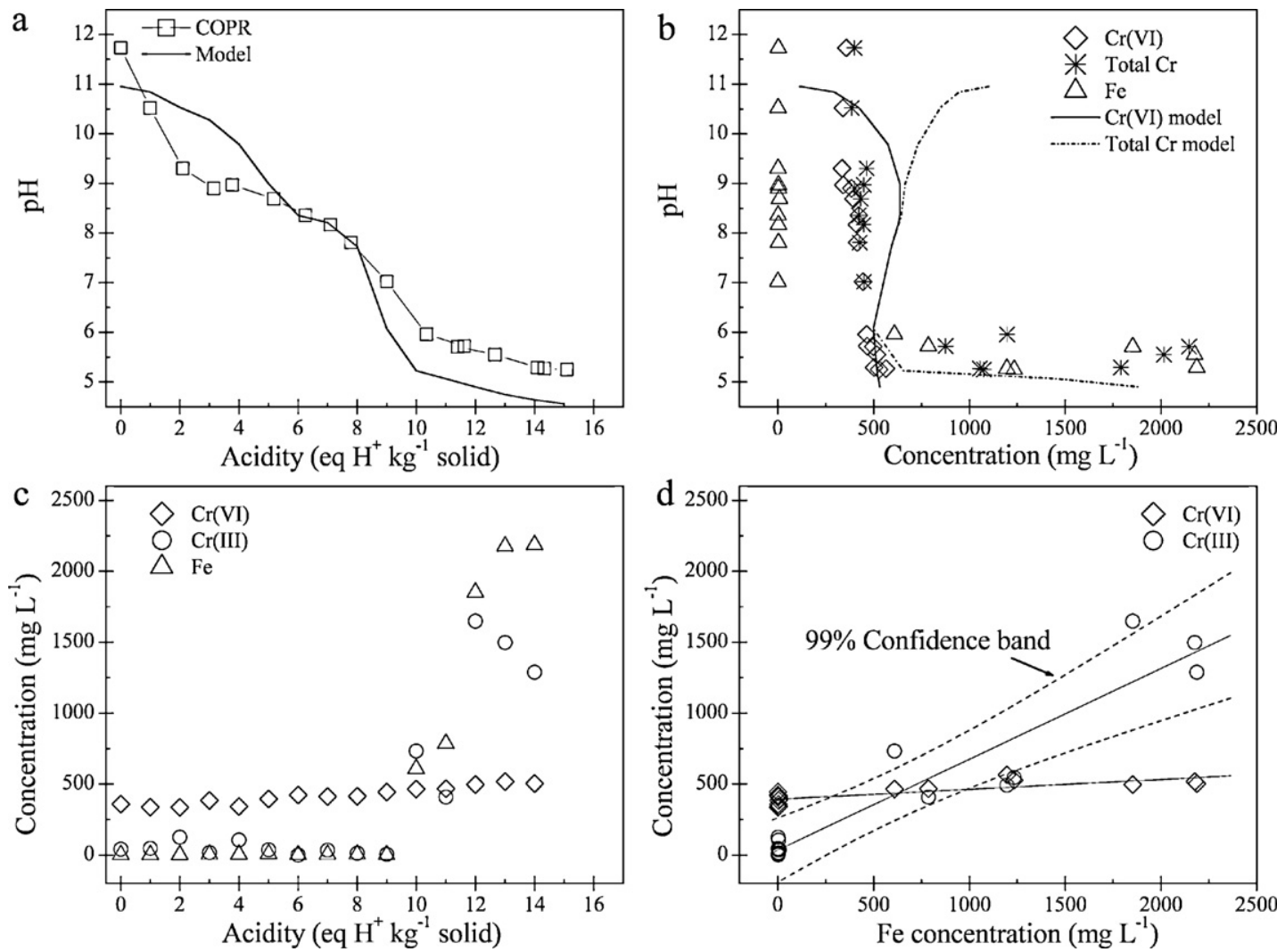

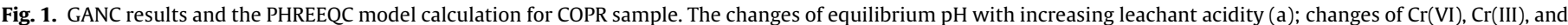

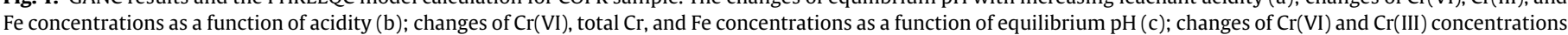
as a function of Fe concentration (d) 


\subsection{Immobilization of $\mathrm{Cr}(\mathrm{VI})$ by $\mathrm{nZVI}$}

\subsection{1. $\mathrm{Cr}(\mathrm{VI})$ immobilizing efficiency}

The nZVI addition significantly reduced the $\mathrm{Cr}(\mathrm{VI})$ leachability as determined by TCLP and HJ (Table 1 ). For example, the $\mathrm{Cr}(\mathrm{VI})$ concentration in TCLP leachate decreased from $330 \mathrm{mg} \mathrm{L}^{-1}$ in untreated COPR sample to $64 \mathrm{mg} \mathrm{L}^{-1}$ with $2 \% \mathrm{nZVI}$ addition (Inc-2). The $\mathrm{pH}$ in the TCLP leachate of untreated COPR sample was slightly reduced to 9.1 because of the high GANC of COPR (Fig. 1a). A remarkable $\mathrm{Cr}(\mathrm{VI})$ immobilization was achieved with $6 \%$ and $10 \%$ nZVI addition, where the $\mathrm{Cr}(\mathrm{VI})$ leachate concentration was below the detection limit $\left(20 \mu \mathrm{g} \mathrm{L}^{-1}\right)$. Our experimental observations agree well with thermodynamic calculations as shown in the pe-pH diagram in Fig. S2 and confirm that $\mathrm{Cr}$ (III) should be the stable $\mathrm{Cr}$ species with $6 \%$ and $10 \%$ nZVI addition.

Our previous study suggests that cement can be successfully used for $\mathrm{Cr}$ (III) immobilization in soils [33]. We therefore hypothesized an approach to reduce the nZVI dosage by a two-step route: reducing $\mathrm{Cr}(\mathrm{VI})$ in COPR with $\mathrm{nZVI}$ and subsequently immobilizing the waste with cement. The results show that $25 \%$ cement addition after nZVI incubation (CInc-2) lowered $\mathrm{Cr}(\mathrm{VI})$ and total $\mathrm{Cr}$ concentrations in TCLP leachate from 64.3 and $74.1 \mathrm{mg} \mathrm{L}^{-1}$ in Inc2 sample, respectively, to 32.1 and $40.3 \mathrm{mg} \mathrm{L}^{-1}$ (Table 1 ). Although cement addition resulted in approximately $50 \%$ additional decrease in leachate $\mathrm{Cr}$ concentrations, more than $30 \mathrm{mg} \mathrm{L}^{-1}$ of $\mathrm{Cr}(\mathrm{VI})$ in CInc-2 sample was leached out which was far beyond the current regulatory limit of $5 \mathrm{mg} \mathrm{L}^{-1}$ for a nonhazardous waste characterized by the US EPA. The results signifies that cement as one of the most commonly used S/S-treatment binders was ineffective in $\mathrm{Cr}(\mathrm{VI})$ immobilization in COPR samples. In order to achieve complete $\mathrm{Cr}(\mathrm{VI})$ reduction and immobilization, sufficient $\mathrm{nZVI}$ should be added. Once $\mathrm{Cr}(\mathrm{VI})$ in COPR was reduced, cement addition may increase the strength of the solid waste to be used for construction purpose [24].

\subsubsection{Effect of nZVI dosage}

The effect of nZVI dosage on $\mathrm{Cr}(\mathrm{VI})$ reduction in COPR was investigated under a constant water content at $33 \%$ with increasing nZVI dosage from 0 to $10 \%$ (Table 1). The concentration of $\mathrm{Cr}(\mathrm{VI})$ in TCLP leachate was $92.1 \mathrm{mg} \mathrm{L}^{-1}$ with $2 \%$ nZVI addition, and substantially decreased to below the detection limit with $6 \%$ and $10 \%$ nZVI addition. The results indicated that $\mathrm{Cr}(\mathrm{VI})$ reduction were positively related with the $\mathrm{nZVI}$ dosage. A minimum addition of $6 \% \mathrm{nZVI}$ was required to achieve a complete $\mathrm{Cr}(\mathrm{VI})$ reduction in COPR, which is in agreement with the results obtained under slightly different water content (23-33\%).

\subsubsection{Control experiment}

To gain insight of COPR immobilization using nZVI, control experiments were performed by concurrently mixing COPR, nZVI, and cement under a series of concentrations. As shown in Table 2, co-addition of nZVI and cement could reduce the $\mathrm{Cr}(\mathrm{VI})$ leachability, however, more than $100 \mathrm{mg} \mathrm{L}^{-1}$ of $\mathrm{Cr}(\mathrm{VI})$ was still detected in TCLP and HJ leachate. The results of control experiments indicate that simultaneous addition of nZVI and cement could not remediate COPR, which is contrary to incubation results with the same amount of nZVI. Cao and Zhang reported a reduction capacity of 69-72 mg $\mathrm{Cr}(\mathrm{VI}) \mathrm{g}^{-1} \mathrm{nZVI}$, which was obtained from the mass balance calculation of dissolved $\mathrm{Cr}(\mathrm{VI})$ concentration in a slurry of $2 \mathrm{~g}$ COPR with $40 \mathrm{~mL}$ water [22]. The resulting high reduction capacity is indicative of an effective electron transfer between $\mathrm{Cr}(\mathrm{VI})$ and nZVI in their slurry experiments. In stark contrast, the electron transfer was not successfully established in S/S-treated samples with such low water content in the range of $14.2-21.3 \%$ due to water consumption by cementitious reactions. Furthermore, the presence of cement could prevented the effective $\mathrm{Cr}(\mathrm{VI})$ and nZVI availability

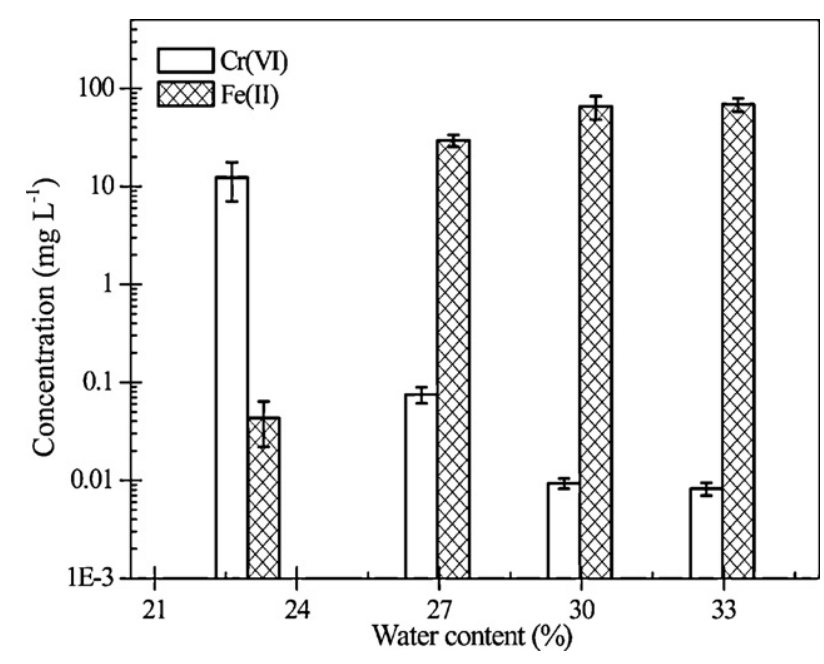

Fig. 2. $\mathrm{Cr}(\mathrm{VI})$ and Fe contents determined with TCLP method from the Inc- 6 (6\% nZVI + COPR) sample at water content $23 \%, 27 \%, 30 \%$, and $33 \%$. The samples were incubated for $7 \mathrm{~d}$.

for the redox reaction, thus resulting in poor $\mathrm{Cr}(\mathrm{VI})$ remediation performance. In addition, because the $\mathrm{Cr}(\mathrm{VI})$ reduction favors at low $\mathrm{pH}$ range as illustrated in the pe-pH diagram (Fig. S2), the high $\mathrm{pH}$ values as a result of cement addition (10.6-12.1, Table 2) may also be responsible for the ineffective $\mathrm{Cr}(\mathrm{VI})$ reduction. The contrast between incubation and S/S treatment samples necessitates further investigations such as water content effect.

\subsubsection{Effect of water content}

To assess the effect of water content on $\mathrm{Cr}(\mathrm{VI})$ reduction, COPR samples were incubated with $6 \% \mathrm{nZVI}$ and increasing water content of $23,27,30$, and $33 \%$. The $\mathrm{Cr}(\mathrm{VI})$ and $\mathrm{Fe}(\mathrm{II})$ concentrations in TCLP leachate are shown in Fig. 2. The leachate $\mathrm{Cr}(\mathrm{VI})$ concentrations decreased from $12.3 \mathrm{mg} \mathrm{L}^{-1}$ to less than $0.02 \mathrm{mg} \mathrm{L}^{-1}$ with the increasing water content from $23 \%$ to $33 \%$, meanwhile, $\mathrm{Fe}(\mathrm{II})$ concentrations increased from $0.04 \mathrm{mg} \mathrm{L}^{-1}$ to $68.5 \mathrm{mg} \mathrm{L}^{-1}$. The change of $\mathrm{Cr}(\mathrm{VI})$ and $\mathrm{Fe}(\mathrm{II})$ concentrations as a function of water content corresponded to the drop of redox potential (Fig. S2), which favors the $\operatorname{Cr}(\mathrm{VI})$ reduction. The results validated our hypothesis that increasing water content lead to an effective electron transfer from nZVI to $\mathrm{Cr}(\mathrm{VI})$.

\subsubsection{Batch tests}

The change of $\mathrm{Cr}(\mathrm{VI})$ contents in solid samples as a function of incubation time is shown in Fig. 3. To facilitate the effective electron transfer between $\mathrm{Cr}(\mathrm{VI})$ and $\mathrm{nZVI}$, the mixtures of COPR and nZVI were incubated under saturated water content (31-36\%) for a period of six months. With the nZVI ratio elevated to above $4 \%$, the $\mathrm{Cr}(\mathrm{VI})$ content in COPR diminished to less than $0.01 \mathrm{~g} \mathrm{~kg}^{-1}$ within $24 \mathrm{~h}$ and remained unchanged thereafter. The $\mathrm{Cr}(\mathrm{VI})$ content in Fig. 3 was determined using alkaline digestion method which might underestimate the $\mathrm{Cr}(\mathrm{VI})$ content because the residual nZVI might reduce the liberated $\mathrm{Cr}(\mathrm{VI})$ during digestion [34]. Therefore, in situ method such as XANES should provide complementary evidence in accurate determination of $\mathrm{Cr}$ speciation.

\subsubsection{XANES spectroscopy}

The XANES analysis was performed to investigate the effectiveness of $\mathrm{Cr}(\mathrm{VI})$ reduction in COPR, and the spectra including standard reference samples are shown in Fig. 4. The XANES spectrum for $\mathrm{Cr}(\mathrm{VI})$ showed a well-defined pre-edge peak over a $5 \mathrm{eV}$ interval starting at approximately $5992 \mathrm{eV}$. The $\mathrm{Cr}_{2} \mathrm{O}_{3}$ standard showed a broad peak starting at $5998 \mathrm{eV}$. The distinct pre-peak feature of $\mathrm{Cr}(\mathrm{VI})$ allows for $\mathrm{Cr}$ speciation in solid samples through a robust 
Table 2

Physical and chemical properties, XANES and leaching tests results for S/S treated COPR samples.

\begin{tabular}{|c|c|c|c|c|c|c|c|c|c|}
\hline \multirow[t]{2}{*}{ Sample } & \multirow[t]{2}{*}{$\mathrm{pH}$} & \multirow[t]{2}{*}{ Water (\%) } & \multicolumn{3}{|c|}{ TCLP } & \multicolumn{3}{|l|}{$\mathrm{HJ}$} & \multirow{2}{*}{$\begin{array}{l}\text { XANES } \\
\mathrm{Cr} \%{ }^{\mathrm{a}}\end{array}$} \\
\hline & & & $\overline{\mathrm{pH}}$ & $\mathrm{Cr}(\mathrm{VI})\left(\mathrm{mg} \mathrm{L}^{-1}\right)$ & $\overline{\mathrm{Cr}} \% \mathrm{a}$ & $\overline{\mathrm{pH}}$ & $\mathrm{Cr}(\mathrm{VI})\left(\mathrm{mg} \mathrm{L}^{-1}\right)$ & $\overline{\mathrm{Cr}} \%{ }^{\mathrm{a}}$ & \\
\hline COPR & 11.7 & 17.0 & 9.1 & $330 \pm 39$ & 52 & 11.6 & $453 \pm 36$ & 36 & $39 \pm 1$ \\
\hline $10 \% \mathrm{C}$ & 11.0 & 14.7 & 8.9 & $342 \pm 35$ & 55 & 11.6 & $583 \pm 33$ & 47 & - \\
\hline $25 \% C$ & 12.1 & 14.2 & 9.0 & $314 \pm 26$ & 57 & 11.9 & $466 \pm 24$ & 43 & $33 \pm 1$ \\
\hline LCLFe & 11.8 & 19.7 & 8.8 & $183 \pm 21$ & 34 & 11.6 & $261 \pm 23$ & 25 & - \\
\hline LCHFe & 11.8 & 21.3 & 9.1 & $118 \pm 24$ & 25 & 11.8 & $132 \pm 12$ & 14 & - \\
\hline HCLFe & 12.0 & 16.3 & 9.5 & $211 \pm 17$ & 43 & 12.0 & $222 \pm 19$ & 23 & - \\
\hline $\mathrm{HCHFe}$ & 12.1 & 17.6 & 9.4 & $101 \pm 25$ & 23 & 12.0 & $112 \pm 18$ & 13 & $22 \pm 2$ \\
\hline $2.5 \% \mathrm{Fe}$ & 10.6 & 21.0 & 8.8 & $205 \pm 18$ & 36 & 12.0 & $321 \pm 27$ & 28 & - \\
\hline $6 \% \mathrm{Fe}$ & 11.3 & 20.3 & 9.0 & $126 \pm 21$ & 25 & 11.4 & $217 \pm 16$ & 21 & $27 \pm 2$ \\
\hline
\end{tabular}

a $\mathrm{Cr} \%$ stands for the percentage content of $\mathrm{Cr}(\mathrm{VI})$ in the leachable total $\mathrm{Cr}$.

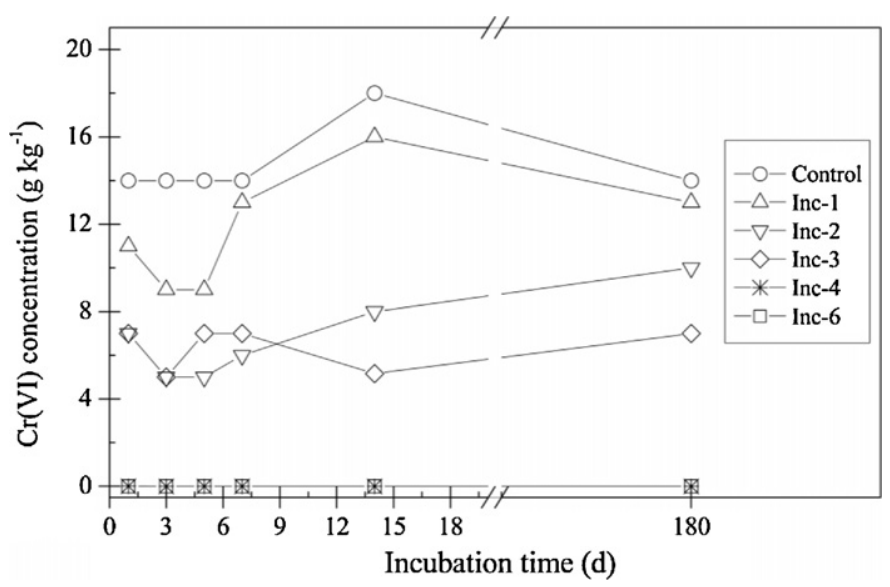

Fig. 3. Changes of $\mathrm{Cr}(\mathrm{VI})$ contents determined with alkaline digestion method as a function of incubation time. Control (untreated COPR); Inc-1 (1\% nZVI + COPR); Inc-2 (2\% nZVI + COPR); Inc-3 (3\% nZVI + COPR); Inc-4 (4\% nZVI + COPR); Inc-6 (6\% $\mathrm{nZVI}+\mathrm{COPR})$

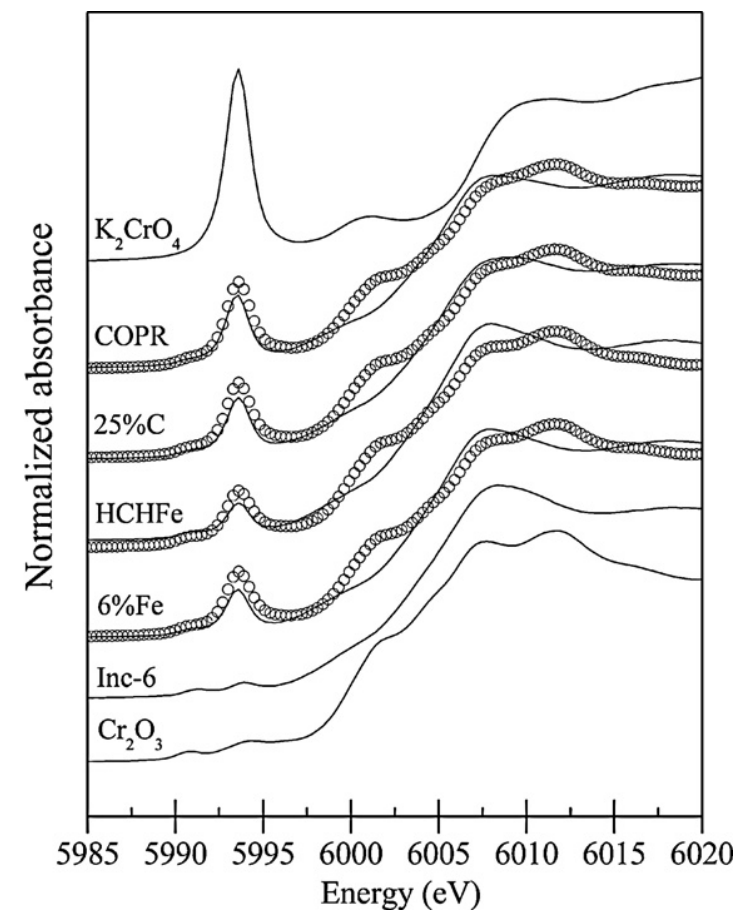

Fig. 4. Experimental observed (solid line) and linear combination fitted (dotted line) chromium K-edge XANES spectra for $\mathrm{K}_{2} \mathrm{CrO}_{4}, \mathrm{Cr}_{2} \mathrm{O}_{3}$, COPR, and treated samples. 25\% C: S/S treatment with $25 \%$ cement; HCHFe: S/S treatment with $25 \%$ cement and $6 \%$ nZVI; $6 \%$ Fe: S/S treatment with 6\% nZVI; Inc-6: incubation with 6\% nZVI. fitting procedure using a least-square linear combination (LC) of the standards. The results of LC fitting are listed in Table 2. Approximately $39 \%$ of total $\mathrm{Cr}$ was present as $\mathrm{Cr}(\mathrm{VI})$ in untreated COPR, which was in agreement with the result of alkaline digestion. The conventional S/S treatment could only lower the $\mathrm{Cr}(\mathrm{VI})$ content from $39 \%$ for the untreated COPR sample to $22 \%$ with $6 \%$ nZVI and $25 \%$ cement addition (HCHFe). In contrast, no $\mathrm{Cr}(\mathrm{VI})$ pre-peak was observed in the Inc-6 sample (Fig. 4), which suggests complete $\mathrm{Cr}(\mathrm{VI})$ reduction in this $\mathrm{nZVI}$ incubation sample.

\subsubsection{X-ray powder diffraction (XRPD) analysis}

XRPD patterns of untreated and treated COPR samples are shown in Fig. 5. The mineral assemblage of untreated COPR in this study was consistent with COPR mineralogy reported previously $[35,36]$. $\mathrm{Cr}(\mathrm{VI})$-bearing minerals identified in the untreated COPR included hydrocalumite and katoite hydrogarnet, which are demonstrated hosts for $\mathrm{Cr}(\mathrm{VI})$ in COPR samples through anionic substitution $[35,37]$. The diminished peak intensity of katoite in treated samples indicated that the mineral substantially dissolved. No new $\mathrm{Cr}$ (III) and iron phases were detected in nZVI treated samples by XRPD, indicating the formation of amorphous rather than crystalline materials. The same amorphous $\mathrm{Cr}(\mathrm{III})$ products were reported by Graham et al. using $\mathrm{CaS}_{X}$ as reductant for the COPR treatment [13].

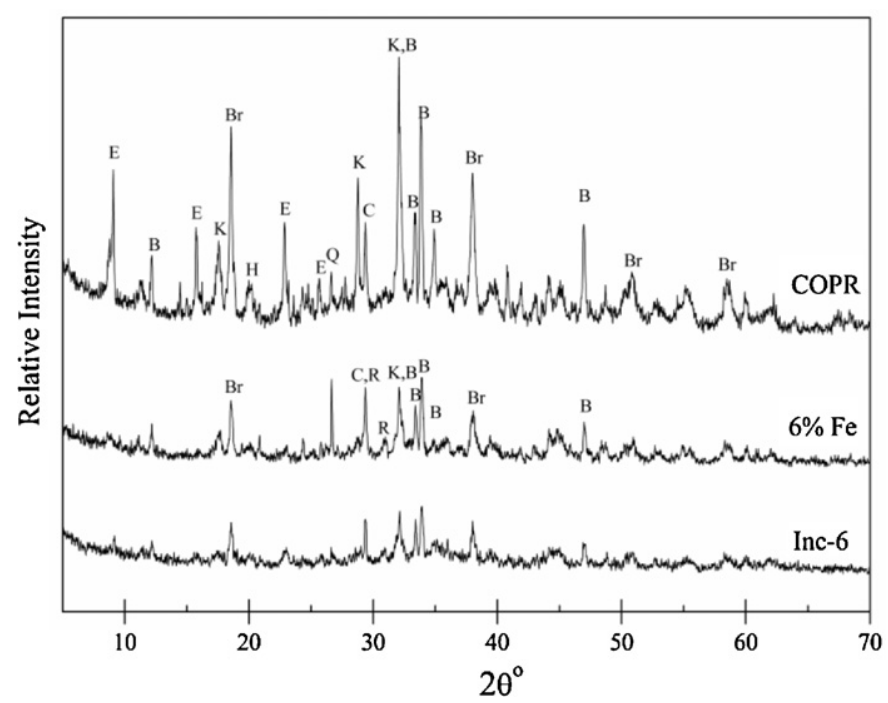

Fig. 5. The XRPD patterns for the untreated and treated COPR. $6 \% \mathrm{Fe}: \mathrm{S} / \mathrm{S}$ treatment with $6 \%$ nZVI; Inc-6: incubation with $6 \%$ nZVI. B: brownmillerite; Br: brucite; C: calcite; E: ettringite; K: katoite; Q: quartz; R: rustumite. 


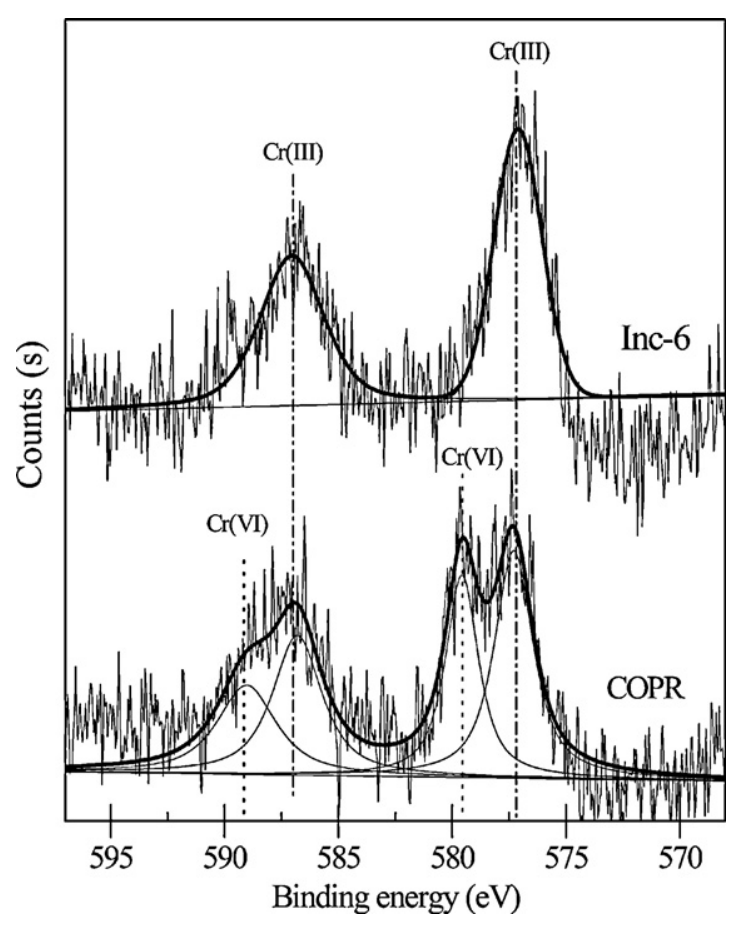

Fig. 6. XPS survey of chromium 2p, for the untreated COPR sample and $6 \%$ nZVI incubated sample (Inc-6).

\subsubsection{Analysis of $\mathrm{Cr}(\mathrm{VI})$ reduction by XPS}

To confirm the $\mathrm{Cr}(\mathrm{VI})$ reduction in the sample incubated with 6\% nZVI (Inc-6), surface sensitive XPS analyses were performed. Detailed XPS surveys on $\mathrm{Cr} 2 \mathrm{p}$ region with mathematical curve fitting by using a least-squares fit of Gaussian-Lorentzian line shape are shown in Fig. 6. Four $\mathrm{Cr}$ photo-electron peaks were observed for the untreated COPR sample where two $2 \mathrm{p}_{3 / 2}$ peaks were centered at 577.3 and $579.6 \mathrm{eV}$ and two $2 \mathrm{p}_{1 / 2}$ peaks at 586.9 and $589.0 \mathrm{eV}$. The binding energies of the $\mathrm{Cr} 2 \mathrm{p}_{3 / 2}$ peak at $577.3 \mathrm{eV}$ and the $\mathrm{Cr} 2 \mathrm{p}_{1 / 2}$ peak at $586.9 \mathrm{eV}$ were consistent with reported values for $\mathrm{Cr}_{2} \mathrm{O}_{3}$, $\mathrm{CrOOH}$, and $\mathrm{Cr}(\mathrm{OH})_{3}$ which was in the energy range 576.2-577.5 eV for $2 \mathrm{p}_{3 / 2}$ and $586.7-587.0 \mathrm{eV}$ for $2 \mathrm{p}_{1 / 2}$, respectively [38-40]. Furthermore, the magnitude of the spin-orbit splitting (SOS) between these two peaks was $9.6 \mathrm{eV}$, which was the characteristic of $\mathrm{Cr}$ (III) with reported SOS of 9.7-9.9eV [41]. The binding energy of the $2 \mathrm{p}_{3 / 2}$ peak at $579.6 \mathrm{eV}$ was comparable to reported values for $\mathrm{Cr}(\mathrm{VI})$ which range from 579.0 to $579.8 \mathrm{eV}$ [42]. The SOS for $\mathrm{Cr}(\mathrm{VI})$ was $9.4 \mathrm{eV}$, in agreement with the reported range 9.2-9.4 eV [39,43].

A comparison of peak area between $\mathrm{Cr}(\mathrm{III})$ and $\mathrm{Cr}(\mathrm{VI})$ indicated that $\mathrm{Cr}(\mathrm{VI})$ accounted for about $43 \%$ of total $\mathrm{Cr}$ on the surface of COPR particles. Further analysis of XPS spectrum for the sample incubated with nZVI suggested that the reduction of $\mathrm{Cr}(\mathrm{VI})$ to $\mathrm{Cr}$ (III) was complete. The two peaks located at 577.1 and $586.9 \mathrm{eV}$ signified that only $\mathrm{Cr}(\mathrm{III})$ exists in the Inc- 6 sample. In addition, the SOS between $2 \mathrm{p}_{3 / 2}$ and $2 \mathrm{p}_{1 / 2}(9.9 \mathrm{eV})$ demonstrated the presence of $\mathrm{Cr}$ (III) compounds [43].

Appreciable amounts of $\mathrm{Cr}(\mathrm{VI})$ were on the surface of COPR particles as evidenced by the surface sensitive XPS analysis (Fig. 6). Once nZVI attached to the COPR surface, nZVI would transfer electrons to $\mathrm{Cr}(\mathrm{VI})$ in proximity. However, a large amount of $\mathrm{Cr}(\mathrm{VI})$ was incorporated in the solid matrix which was not available to nZVI. Because the solid matrix comprised of metal oxides and $\mathrm{SiO}_{2}$ is not conductive, effective electron transfer could not be achieved in the absence of water. Based on our experimental results with $6 \% \mathrm{nZVI}$ addition (Table 2), the $\mathrm{Cr}(\mathrm{VI})$ content was reduced from $39 \%$ in COPR to $27 \%$ under $20.3 \%$ water content. When the water content was increased to about 33\% (Inc-6 in Fig. 4), all $\mathrm{Cr}(\mathrm{VI})$ was reduced to $\mathrm{Cr}(\mathrm{III})$. The results suggested that the redox reaction mainly occurred in the solid/liquid interface with water facilitating the electron transfer.

\section{Conclusions}

Effective COPR remediation technique presents a great challenge. To explore $\mathrm{Cr}(\mathrm{VI})$ immobilization in COPR using nZVI, COPR samples were obtained from a waste site in China containing $43.2 \mathrm{~g} \mathrm{~kg}^{-1}$ total $\mathrm{Cr}$. The $\mathrm{Cr}(\mathrm{VI})$ content was $37 \%$ of total $\mathrm{Cr}$ determined using alkaline digestion, which was in agreement with the XANES analysis (39\%). XPS analysis suggested that more $\mathrm{Cr}(\mathrm{VI})$ (43\%) was detected in the COPR surface than in the bulk. Results of GANC experiment and PHREEQC calculation showed that when $\mathrm{pH}$ was lowered from 11.7 to 7.0 , leachate $\mathrm{Cr}(\mathrm{VI})$ concentrations slightly increased from 358 to $445 \mathrm{mg} \mathrm{L}^{-1}$ which contributed over $90 \%$ of dissolved $\mathrm{Cr}$. Conventional S/S treatment with nZVI and cement could reduce the TCLP $\mathrm{Cr}(\mathrm{VI})$ concentration from $330 \mathrm{mg} \mathrm{L}^{-1}$ for the untreated COPR sample to around $100 \mathrm{mg} \mathrm{L}^{-1}$. The Cr XANES analysis showed that over $22 \%$ of total $\mathrm{Cr}$ was in the $\mathrm{Cr}(\mathrm{VI})$ form in S/S-treated samples which contributed to the high $\mathrm{Cr}(\mathrm{VI})$ leachability. Results of alkaline digestion, XANES, and XPS demonstrated that incubating COPR with nZVI under water content higher than $27 \%$ could result in a nearly complete $\mathrm{Cr}(\mathrm{VI})$ reduction and less than $0.1 \mathrm{mg} \mathrm{L}^{-1}$ leachate $\mathrm{Cr}(\mathrm{VI})$. The results implied that remediation approaches using nZVI to immobilize $\mathrm{Cr}(\mathrm{VI})$ in COPR should be successful with sufficient water content to facilitate electron transfer between $\mathrm{Cr}(\mathrm{VI})$ and nZVI. The results shed new light on $\mathrm{nZVI}$ application in COPR remediation.

\section{Acknowledgments}

We acknowledge the staff on beamline BL3C1 at PLS for their assistance with XAFS data collection. The research is supported by the National Natural Science Foundation of China (20890112, 20921063, 41023005).

\section{Appendix A. Supplementary data}

Supplementary data associated with this article can be found, in the online version, at doi:10.1016/j.jhazmat.2012.02.049.

\section{References}

[1] NIH, NTP Technical Report on the Toxicity Studies of Sodium Dichromate Dihydrate, NIH, Washington, DC, 2007.

[2] J.G. Farmer, E. Paterson, R.J.F. Bewley, J.S. Geelhoed, S. Hillier, J.C.L. Meeussen, D.G. Lumsdon, R.P. Thomas, M.C. Graham, The implications of integrated assessment and modelling studies for the future remediation of chromite ore processing residue disposal sites, Sci. Total Environ. 360 (2006) 90-97.

[3] J.S. Geelhoed, J.C.L. Meeussen, M.J. Roe, S. Hillier, R.P. Thomas, J.G. Farmer, E. Paterson, Chromium remediation or release? Effect of iron(II) sulfate addition on chromium(VI) leaching from columns of chromite ore processing residue, Environ. Sci. Technol. 37 (2003) 3206-3213.

[4] G.T. Shi, Z.L. Chen, S.Y. Xu, J. Zhang, L. Wang, C.J. Bi, J.Y. Teng, Potentially toxic metal contamination of urban soils and roadside dust in Shanghai, China, Environ. Pollut. 156 (2008) 251-260.

[5] S. Dantu, Heavy metals concentration in soils of southeastern part of Ranga Reddy district, Andhra Pradesh, India, Environ. Monit. Assess. 149 (2009) 213-222.

[6] T. Wang, M. He, Q. Pan, A new method for the treatment of chromite ore processing residues, J. Hazard. Mater. 149 (2007) 440-444.

[7] J.M. Tinjum, C.H. Benson, T.B. Edil, Mobilization of $\mathrm{Cr}(\mathrm{VI})$ from chromite ore processing residue through acid treatment, Sci. Total Environ. 391 (2008) 13-25.

[8] R. Badreddine, A.N. Humez, U. Mingelgrin, A. Benchara, F. Meducin, R. Prost, Retention of trace metals by solidified/stabilized wastes: assessment of longterm metal release, Environ. Sci. Technol. 38 (2004) 1383-1398.

[9] T.L. Rinehart, D.G. Schulze, R.M. Bricka, S. Bajt, E.R. Blatchley, Chromium leaching vs. oxidation state for a contaminated solidified/stabilized soil, J. Hazard. Mater. 52 (1997) 213-221.

[10] C.D. Palmer, P.R. Wittbrodt, Process affecting the remediation of chromiumcontaminated sites, Environ. Health Perspect. 92 (1991) 25-40. 
[11] M. Wazne, A.C. Jappilla, D.H. Moon, S.C. Jagupilla, C. Christodoulatos, M.G. $\mathrm{Kim}$, Assessment of calcium polysulfide for the remediation of hexavalent chromium in chromite ore processing residue (COPR), J. Hazard. Mater. 143 (2007) 620-628.

[12] M. Wazne, D.H. Moon, S.C. Jagupilla, C. Christodoulatos, D. Dermatas, M. Chrysochoou, Remediation of chromite ore processing residue using ferrous sulfate and calcium polysulfide, Geosci. J. 11 (2007) 105-110.

[13] M.C. Graham, J.G. Farmer, P. Anderson, E. Paterson, S. Hillier, D.G. Lumsdon, R.J.F. Bewley, Calcium polysulfide remediation of hexavalent chromium contamination from chromite ore processing residue, Sci. Total Environ. 364(2006) 32-44.

[14] D. Dermatas, M. Chrysochoou, D.H. Moon, D.G. Grubb, M. Wazne, C. Christodoulatos, Ettringite-induced heave in chromite ore processing residue (COPR) upon ferrous sulfate treatment, Environ. Sci. Technol. 40 (2006) 5786-5792.

[15] D.H. Moon, M. Wazne, S.C. Jaupilla, C. Christodoulatos, M.G. Kim, A. Koutsospyros, Particle size and $\mathrm{pH}$ effects on remediation of chromite ore processing residue using calcium polysulfide $\left(\mathrm{CaS}_{5}\right)$, Sci. Total Environ. 399 (2008) 2-10.

[16] L.E. Eary, D. Rai, Chromate removal from aqueous wastes by reduction with ferrous ion, Environ. Sci. Technol. 22 (1988) 972-977.

[17] J.S. Geelhoed, J.C.L. Meeussen, D.G. Lumsdon, S. Hillier, M.J. Roe, R.P. Thomas, R.J.F. Bewley, J.G. Farmer, E. Paterson, Modelling of chromium behaviour and transport at sites contaminated with chromite ore processing residue: implications for remediation methods, Environ. Geochem. Health 23 (2001) 261-265.

18] S.M. Ponder, J.G. Darab, T.E. Mallouk, Remediation of $\mathrm{Cr}(\mathrm{VI})$ and $\mathrm{Pb}$ (II) aqueous solutions using supported, nanoscale zero-valent iron, Environ. Sci. Technol. 34 (2000) 2564-2569.

[19] Y.H. Xu, D.Y. Zhao, Reductive immobilization of chromate in water and soil using stabilized iron nanoparticles, Water Res. 41 (2007) 2101-2108.

[20] T.Y. Liu, L. Zhao, D.S. Sun, X. Tan, Entrapment of nanoscale zero-valent iron in chitosan beads for hexavalent chromium removal from wastewater, J. Hazard. Mater. 184 (2010) 724-730.

[21] L.N. Shi, X. Zhang, Z.L. Chen, Removal of chromium (VI) from wastewater using bentonite-supported nanoscale zero-valent iron, Water Res. 45 (2011) 886-892.

[22] H.S. Cao, W.X. Zhang, Stabilization of chromium ore processing residue (COPR) with nanoscale iron particles, J. Hazard. Mater. 132 (2006) 213-219.

[23] C.B. Wang, W.X. Zhang, Synthesizing nanoscale iron particles for rapid and complete dechlorination of TCE and PCBs, Environ. Sci. Technol. 31 (1997) 2154-2156.

[24] C. Jing, X. Meng, G.P. Korfiatis, Lead leachability in stabilized/solidified soil samples evaluated with different leaching tests, J. Hazard. Mater. 114 (2004) 101-110.

[25] US EPA, Test methods for evaluating solid waste, physical/chemical methods, SW-846, in: Method 3050B Acid Digestion of Sediments, Sludges and Soils, 3rd ed., 1992.

[26] US EPA, Test methods for evaluating solid waste, physical/chemical methods, SW-846, in: Method 3060A Alkaline Digestion for Hexavalent Chromium, 3rd ed., 1992
[27] US EPA, Test methods for evaluating solid waste physical/chemical methods, SW-846, in: Method 7196A Chromiu, Hexavalent (Colorimetric), 3rd ed., 1992

[28] A.D. Eaton, L.S. Clesceri, A.E. Greenberg (Eds.), Standard Methods for the Examination of Water and Wastewater, 4500-S2-D, 19th ed., American Public Health Association, Washington, DC, 1995

[29] Generalized acid neutralization capacity test, in: J. Isenburg, M. Moore, T.M Gilliam, C.C. Wiles (Eds.), Stabilization and Solidification of Hazardous, Radioactive, and Mixed Wastes, ASTM Special Technical Publication, No. 1123, vol. 2 ASTM, Philadelphia, PA, USA, 1992, pp. 361-377.

[30] US EPA, Physical/chemical methods, test methods for evaluating solid waste, SW-846, in: Method 1311 Toxicity Characteristic Leaching Procedure, 3rd ed., 1992.

[31] CEPA, Solid Waste Extraction Procedure for Leaching Toxicity Sulfuric Acid \& Nitric Acid Method (HJ/T299-2007), 2007.

[32] D.L. Parkhurst, C.A.J. Appelo, User's Guide to PHREEQC (Version 2): A Computer Program for Speciation, Batch Reaction, One Dimensional Transport, and Inverse Geochemical Calculations, US Geological Survey Water Resources Investigations, 1999, pp. 99-4295

[33] C.Y. Jing, S.Q. Liu, G.P. Korfiatis, X.G. Meng, Leaching behavior of $\mathrm{Cr}(\mathrm{III})$ in stabilized/solidified soil, Chemosphere 64 (2006) 379-385.

[34] B.R. James, J.C. Petura, R.J. Vitale, G.R. Mussoline, Hexavalent chromium extraction from soils: a comparison of 5 methods, Environ. Sci. Technol. 29 (1995) 2377-2381.

[35] J.S. Geelhoed, J.C.L. Meeussen, S. Hillier, D.G. Lumsdon, R.P. Thomas, J.G. Farmer, E. Paterson, Identification and geochemical modeling of processes controlling leaching of $\mathrm{Cr}(\mathrm{VI})$ and other major elements from chromite ore processing residue, Geochim. Cosmochim. Acta 66 (2002) 3927-3942.

[36] M. Chrysochoou, D. Dermatas, Application of the rietveld method to assess chromium(VI) speciation in chromite ore processing residue, J. Hazard. Mater. 141 (2007) 370-377

[37] S. Hillier, M.J. Roe, J.S. Geelhoed, A.R. Fraser, J.G. Farmer, E. Paterson, Role of quantitative mineralogical analysis in the investigation of sites contaminated by chromite ore processing residue, Sci. Total Environ. 308 (2003) 195-210.

[38] L. Dupont, E. Guillon, Removal of hexavalent chromium with a lignocellulosic substrate extracted from wheat bran, Environ. Sci. Technol. 37 (2003) 4235-4241.

[39] X.Q. Li, J.S. Cao, W.X. Zhang, Stoichiometry of $\mathrm{Cr}(\mathrm{VI})$ immobilization using nanoscale zerovalent iron (nZVI): a study with high-resolution X-ray photoelectron spectroscopy (HR-XPS), Ind. Eng. Chem. Res. 47 (2008) 2131-2139.

[40] L. Legrand, A. El Figuigui, F. Mercier, A. Chausse, Reduction of aqueous chromate by $\mathrm{Fe}(11) / \mathrm{Fe}(111)$ carbonate green rust: kinetic and mechanistic studies Environ. Sci. Technol. 38 (2004) 4587-4595.

[41] M. Mullet, S. Boursiquot, J.J. Ehrhardt, Removal of hexavalent chromium from solutions by mackinawite, tetragonal FeS, Colloids Surf. A 244 (2004) 77-85.

[42] S. Boursiquot, M. Mullet, J.J. Ehrhardt, XPS study of the reaction of chromium (VI) with mackinawite (FeS), Surf. Interface Anal. 34 (2002) 293-297.

[43] M.A. Olazabal, N.P. Nikolaidis, S.A. Suib, J.M. Madariaga, Precipitation equilibria of the chromium(VI)/iron(III) system and spectroscopic characterization of the precipitates, Environ. Sci. Technol. 31 (1997) 2898-2902. 